\title{
Tindak Pidana Perdagangan Satwa Liar Dilindungi yang Berimplikasi Tindak Pidana Pencucian Uang
}

\author{
Ferna Lukmia Sutra \\ fernalukmiasutra@gmail.com \\ Universitas Airlangga
}

\begin{abstract}
Keywords: Abstract
The Trade in Protected wildlife is biological natural resources that needs to be protected. However, the

Protected Wildlife; potential of natural resources began to be disrupted as the practice of trading in protected Conservation; animal in various methods. Increased trade in protected wildlife occurs as economic Money Laundering. factors, weak law enforcement, high market demand, and the suspect have national and international networks. Regulation related to protected animal trade is Conservation of Biological Resources and their Ecosystems Law seem have not accommodate the subject of corporate actors and deterrent effect. Law enforcement needs to use various existing regulation, one of them is use money laundering instrument.. This legal research discusses the protected animal trade as origin crime in money laundering and the responsibility of the suspect in the trade of protected wildlife that implicates the crime of money laundering with the research method of the state approach and conceptual approach. Based on the study it can be known that some protected animal trade pratices difficult to detect, one of them as the result of criminal acts have entered the legal market. This shows the important of legal instrument to ensnare the actor who process money laundering. The conclusion of this study are Conservation of Biological Resources and their Ecosystems Law can be qualified as a predicate crime in money laundering crime. The liabiected wildife traffickers can implicate to money laundering, so the Prevention and Eradication of Money Laundering law can be a legal instrument to combat this crime.
\end{abstract}

\section{Kata Kunci: \\ Abstrak}

Perdagangan

Satwa Liar

Satwa liar dilindungi merupakan sumber daya alam hayati yang perlu dijaga.

Dilindungi;

Konservasi;

Namun potensi sumber daya alam Indonesia mulai terganggu karena praktek perdagangan satwa liar dilindungi pada berbagai macam modus. Peningkatan kejahatan tersebut terjadi karena faktor ekonomi, lemahnya penegakkan Pencucian Uang. hukum, permintaan pasar yang tinggi, dan pelaku memiliki jaringan nasional dan internasional. Regulasi terkait perdagangan satwa liar dilindungi yakni Undang-Undang Konservasi Sumber Daya alam Hayati dan Ekosistemnya nampakanya belum mengakomodasi subjek pelaku korporasi dan efek jera. Lembaga penegak hukum perlu mengggunakan berbagai peraturan yang ada salah satunya menggunakan instrumen pencucian uang. Penelitian hukum ini membahas perdagangan satwa liar dilindungi sebagai tindak pidana asal dalam tindak pidana pencucian uang dan pertanggungjawaban pelaku perdagangan satwa liar dilindungi berimplikasi tindak pidana pencucian uang dengan metode pendekatan perundang-undangan dan pendekatan konseptual. Berdasarkan pembahasan dapat diketahui bahwa beberapa praktek perdagangan satwa dilindungi sulit terdeteksi, salah satunya karena hasil tindak pidana telah masuk pada legal market. Hal ini menunjukkan pentingnya instrumen hukum untuk menjerat subjek pelaku yang memproses pencucian uang. Hasil dari penelitian dapat disimpulkan bahwa Undang-Undang Konservasi Sumber Daya alam Hayati dan Ekosistemnya dapat memenuhi syarat sebagai tindak pidana 
Ferna Lukmia: Tindak Pidana Perdagangan...

asal di dalam tindak pidana pencucian uang. Pertanggungjawaban pelaku perdagangan satwa liar dilindungi dapat berimplikasi pada tindak pidana pencucian uang, sehingga Undang-Undang Pencegahan dan Pemberantasan Tindak Pidana Pencucian Uang dapat menjadi instrumen hukum untuk memberantas kejahatan ini.

\section{Pendahuluan}

Copyright $\odot 2020$ Universitas Airlangga

Indonesia adalah negara yang memiliki potensi hutan hujan tropis terluas ketiga di dunia setelah Brasil dan Kongo. ${ }^{1}$ Hal menimbulkan dampak kepada Indonesia sebagai negara yang kaya akan sumber daya alam dengan keanekaragaman flora dan fauna. Terdapat empat unsur yang terkandung dalam definisi hutan sebagaimana Pasal 1 ayat (2) Undang-Undang Nomor 41 Tahun 1999 tentang Kehutanan yakni unsur lapangan yang cukup luas (tanah hutan), unsur pohon flora dan fauna, unsur lingkungan dan unsur penetapan pemerintah. Unsur pertama hingga ketiga merupakan persekutuan hidup yang tidak dapat dipisahkan satu dengan yang lain. ${ }^{2}$ Namun, potensi ini ternoda oleh perdagangan satwa liar yang dilindungi. Kegiatan ini merupakan penyebab berkurangnya kekayaan alam yakni satwa khas Indonesia. International Animal Rescue (IAR) Indonesia menyebutkan bahwa kejahatan satwa liar secara global menempati posisi kedua setelah kejahatan narkotika. ${ }^{3} \mathrm{Hal}$ ini menunjukan isu terkait perdagangan satwa liar terlebih satwa liar yang dilindungi merupakan isu lingkungan yang memerlukan perhatian.

Kejahatan Tumbuhan dan Satwa Liar atau yang sering disebut Wildlife Crime sedang ramai dibicarakan. Berdasarkan data WWF Indonesia, kejahatan satwa di Indonesia mencatat ada 8 ton gading gajah beredar di Sumatera selama 10 tahun terakhir, lebih dari 100 orang orangutan diselundupkan keluar negeri tiap tahun, lebih dari 2.000 kukang diperdagangkan di Jawa dan juga diselundupkan ke luar negeri, dan 2.000 ekor tringgiling dijual ilegal keluar negeri setiap bulan serta

\footnotetext{
${ }^{1}$ Ahmad Redi, Hukum Sumber Daya Alam Dalam Sektor Kehutanan (Sinar Grafika 2014).[2].

2 Salim, Dasar-Dasar Hukum Kehutanan (Sinar Grafika 2008).[41].

${ }^{3}$ Petrus Riski, 'Pentingnya Penguatan Hukum dalam Perlindungan Satwa Liar di Indonesia', VOA Indonesia (2019), <https://www.voaindonesia.com/a/pentingnya-penguatan-hukum-dalamperlindungan-satwa-liar-di-indonesia/4825454.html>, Diakses pada tanggal 20 Agustus 2019.
} 
setiap tahun 1 juta telur penyu diperdagangkan di seluruh Indonesia. Beberapa tahun terakhir telah tercatat 74 ekor orangutan diperdagangkan secara daring dan 15 harimau diperdagangkan di facebook. ${ }^{4}$

International Union for Conservation of Nature and Natural resources (IUCN) merupakan organisasi internasional yang didedikasikan untuk konservasi sumber daya alam. Organisasi ini memberikan perlindungan terhadap satwa salah satunya melalui IUCN Red List, yakni daftar yang membahas status konservasi berbagai jenis makhluk hidup seperti satwa yang dikeluarkan oleh IUCN. Daftar ini berisi sembilan klasifikasi satwa yang diatur berdasarkan kriteria jumlah populasi, penyebaran dan resiko kepunahan. Klasifikasi tersebut meliputi punah, punah di alam liar, genting, rentan, hampir terancam, beresiko rendah, informasi kurang, dan tidak dievaluasi. Negara-negara anggota IUCN bersepakat untuk menganjurkan pembatasan perdagangan satwa langka melalui penandatanganan Convention on Interational Trade in Endangered Species of Wild Fauna and Flora (CITES). Konvensi yang biasa disebut sebagai Konvensi Washington ini diratifikasi oleh Indonesia pada tahun 1978. Salah satu dasar hukum yang berkaitan dengan isu perdagangan satwa langka ini adalah Undang-Undang Nomor 5 Tahun 1990 tentang Konservasi Sumber Daya Alam Hayati dan Ekosistemnya (selanjutnya disingkat dengan UU KSDAHE), aturan berisikan asas pelaksanaan konservasi sumber daya alam hayati dan ekosistemnya, yakni pelestarian kemampuan dan pemanfaatan sumber daya alam dan ekosistem secara serasi dan seimbang. Sasaran aturan ini adalah berusaha mengubah sikap mental masyarakat untuk mencintai dan melestarikan lingkungan hidupnya, termasuk sumber daya alam hayati dan ekosistemnya. ${ }^{5}$

Berbagai faktor yang mempengaruhi semakin meningkatnya perdagangan satwa liar yang dilindungi sangat beragam, faktor ekonomi dan lemahnya penegakkan hukum, serta didorong oleh permintaan pasar yang tinggi. Pelaku

${ }^{4}$ Risanti, 'Pelaku Perdagangan Satwa Liar Dilindungi Akan Dijerat UU Pencucian Uang', IAR Indonesia, (2017), <http://www.internationalanimalrescue.or.id/pelaku-perdagangan-satwaliar-dilindungi-akan-dijerat-uu-pencucian-uang/, 10 Maret 2017>, Diakses pada tanggal 25 Februari 2020.

5 Abdullah Marlang, Rina Maryana, Hukum Konservasi Sumber Daya Alam Hayati dan Ekosistemnya (Mitra Wacana Media 2015).[88]. 
Ferna Lukmia: Tindak Pidana Perdagangan...

perdagangan satwa liar yang dilindungi biasanya dijerat menggunakan UU KSDAHE. Hal ini tetap saja tidak menimbulkan efek jera bagi pelaku. Bahkan dewasa ini praktik jual beli ini semakin meningkat. Tidak hanya di sektor nasional saja, jual beli telah dilakukan antar negara dan menggunakan sistem jual beli di media sosial. Bisnis perdagangan satwa liar semakin memiliki celah besar karena banyak sekali komunitas hobi pemelihara hewan. Hal tersebut menunjukkan bahwa perdagangan satwa liar dilindungi merupakan kegiatan kriminal yang memiliki nilai untung yang besar karena permintan dari pembeli yang semakin meningkat.

Protection of Forest Indonesia menyatakan bahwa kerugian yang ditanggung Indonesia berkontribusi terhadap kerugian global perdagangan satwa liar di seluruh dunia yang mencapai antara US\$ 15 miliar hingga US\$ 20 miliar. $^{6}$ Berdasarkan laporan Global Financial Integrity yang berjudul Transnational Crime and the Developing World, yang dipublikasikan pada Maret 2017, aliran dana secara global yang berputar dari tindak kejahatan perdagangan ilegal satwa liar dilindungi mencapai 10 miliar dollar Amerika Serikat setiap tahunnya. Selain itu, perdagangan satwa liar yang dilindungi merupakan usaha yang menguntungkan dan beririsan dengan tindak pidana pencucian uang. Pelaku kejahatan perdagangan satwa liar dilindungi sering menyamarkan hasil tindak pidananya dari aparat hukum.

Penegak hukum dalam praktik perdagangan satwa yang dilindungi cenderung masih menggunakan UU KSDAHE dimana hanya mencantumkan sanksi pidana maksimal saja tidak terdapat sanksi minimal. Penegak hukum merupakan salah satu faktor yang menentukan tercapainya penegakan hukum pidana konservasi sumber daya hayati dalam hal profesionalitas dalam menegakan hukum.

Disamping itu, rezim anti pencucian uang dibangun dengan dilatarbelakangi

${ }^{6}$ Ahmad Nurhasim, 'Indonesia Rugi 9 Triliun Akibat Perdagangan Satwa Liar', Tempo News (online) ( 2016), <https://nasional.tempo.co/read/776900/indonesia-rugi-rp-9-triliun-akibatperdagangan-satwa-liar>, Diakses 23 Agustus 2019. 
oleh semakin maraknya kejahatan pencucian uang yang melibatkan dan menghasilkan harta kekayaan yang sangat besar jumlahnya. Kriminalisasi dari pencucian uang itu sendiri termaktub dalam beberapa pasal di dalam UU Nomor 8 Tahun 2010 tentang Pencegahan dan Pemberantasan Tindak Pidana Pencucian Uang (selanjutnya disebut UU PTPPU). Pelaku tindak pidana pencucian uang biasanya memanfaatkan kecanggihan teknologi untuk menyembunyikan atau menyamarkan harta kekayaan yang diperoleh dari tindak pidana agar tidak mudah untuk dideteksi oleh pengak hukum sehingga uang tersebut seolah-olah merupakan harta kekayaan yang sah. Predicate crime atau tindak pidana asal dalam tindak pidana pencucian uang diatur dalam Pasal 2 UU PTPPU.

Perburuan binatang pada jaman dahulu bertujuan untuk dikonsumsi, namun hal ini mulai bergeser untuk diambil bagian tubuhnya untuk kerajinan, obat-obatan dan untuk kosmetik. Perdagangan satwa memiliki potensi keuntungan yang sangat besar terlebih satwa langka, semakin langka hewan maka semakin mahal harganya. ${ }^{7}$ Pertanggungjawaban pelaku perdaganan satwa yang dilindungi harusnya juga dikenakan pada setiap subjek yang terlibat di dalamnya. Terlebih lagi, pembeli bisa saja merupakan warga negara asing karena modus promosi telah menggunakan media massa atau online dan efek terbesarnya yakni kerugian negara atas perdagangan satwa dilindungi. Tanpa penegakan hukum yang tegas, maka pelaku dapat menggunakan keuntungan finansial atas perdagangan satwa liar dilindungi dan menyembunyikannya ke dalam sistem ekonomi untuk menjadi dasar kekuatan jaringan mereka. Berdasarkan uraian tersebut maka penulis tertarik untuk membahas perdagangan satwa liar dilindungi sebagai tindak pidana asal dalam tindak pidana pencucian uang dan Pertanggungjawaban pelaku perdagangan satwa liar dilindungi berimplikasi tindak pidana pencucian uang.

7 Aristides Yoshua, Agus Purnomo, Fx Adji Samekto, 'Perlindungan Satwa Langka di Indonesia dari Perspektif Convention on Intrenational Trade in Endangered Species of Flora and Fauna (CITES)' (2016) 4 (5) Diponegoro Law Journal.[2]. 


\section{Metode Penelitian}

Tipe penelitian hukum ini adalah penelitian hukum normatif (legal research) dimana ditujukan untuk menemukan kebenaran koherensi. ${ }^{8}$ Pendekatan masalah dalam penelitian ini adalah Pendekatan Perundang-Undangan (Statute Approach) dan Pendekatan Konseptual (Conceptual Approach). Pendekatan perundangundangan (Statute Approach) dilakukan dengan menelaah semua undang-undang dan regulasi yang bersangkut paut dengan isu hukum yang sedang ditangani. ${ }^{9}$ Adapun pendekatan perundang-undangan (Statute Approach) digunakan untuk suatu permasalahan yang memiliki regulasi dan kemudian menggunakan regulasi tersebut untuk menyelesaikan permasalahan yang ada. Pendekatan Konseptual (Conceptual Approach) beranjak dari pandangan-pandangan dan doktrin-doktrin yang berkembang di dalam ilmu hukum. ${ }^{10}$ Terutama mengenai konsep asas kepastian hukum dan asas keadilan guna menghadapi isu hukum yang diteliti.

\section{Perdagangan Satwa Liar Dilindungi Sebagai Tindak Pidana Asal Dalam Tindak}

\section{Pidana Pencucian Uang}

Dalam sistem hukum nasional, terdapat penggolongan jenis satwa. Pada Pasal 20 UU KSDAHE penggolongan tersebut dibagi menjadi dua jenis, yakni satwa yang dilindungi dan satwa yang tidak dilindungi. Sedangkan Pasal 21 UU KSDAHE merinci perbuatan yang dilarang. Pasal tersebut berbunyi:

(1) Setiap orang dilarang untuk:

a. mengambil, menebang, memiliki, merusak, memusnahkan, memelihara, mengangkut, dan memperniagakan tumbuhan yang dilindungi atau bagian-bagiannya dalam keadaan hidup atau mati;

b. mengeluarkan tumbuhan yang dilindungi atau bagian-bagiannya dalam keadaan hidup atau mati dari suatu tempat di Indonesia ke tempat lain di dalam atau di luar Indonesia.

(1) Setiap orang dilarang untuk :

a. menangkap, melukai, membunuh, menyimpan, memiliki, memelihara, mengangkut, dan memperniagakan satwa yang dilindungi dalam keadaan

${ }^{8}$ Peter Mahmud Marzuki, Penelitian Hukum (Kencana Prenadamedia Group 2014).[47].

9 ibid.[133].

${ }^{10}$ ibid.[35]. 
hidup;

b. menyimpan, memiliki, memelihara, mengangkut, dan memperniagakan satwa yang dilindungi dalam keadaan mati;

c. mengeluarkan satwa yang dilindungi dari suatu tempat di Indonesia ke tempat lain di dalam atau di luar Indonesia;

d. memperniagakan, menyimpan atau memiliki kulit, tubuh, atau bagianbagian lain satwa yang dilindungi atau barang-barang yang dibuat dari bagian-bagian tersebut atau mengeluarkannya dari suatu tempat di Indonesia ke tempat lain di dalam atau di luar Indonesia;

e. mengambil, merusak, memusnahkan, memperniagakan, menyimpan atau memiliki telur dan atau sarang satwa yang dillindungi.

Larangan tersebut dikecualikan pada satwa yang digunakan dalam keperluan penelitian, ilmu pengetahuan, dan/atau penyelamatan jenis satwa yang bersangkutan. Daftar jenis satwa liar dilindungi telah termaktub di dalam PP Nomor 7 Tahun 1999 tentang Pengawetan Jenis Tumbuhan dan Satwa yakni pada bagian lampiran.

Berdasarkan Pasal 5 UU KSDAHE, suatu satwa disebut sebagai satwa dilindungi jika telah memenuhi kriteria yakni populasi yang kecil, terdapat penurunan tajam jumlahnya di alam, dan memiliki daerah penyebaran yang terbatas. Pasal 25 UU KSDAHE mengatur bahwa dalam pengiriman atau pengangkutan satwa dilindungi dari dan ke Indonesia atau dari dan keluar wilayah Indonesia wajib dilengkapi sertifikat kesehatan satwa dan dilakukan

Selain itu, aspek lain yang perlu diperhatikan adalah perijinan. Ijin terkait proses kepemilikan atas satwa liar dilindungi harus sesuai dengan Pasal 30 ayat 2 Kepmenhut Nomor 477/Kpts-II/2003 tentang Tata Usaha Pengambilan atau Penangkapan dan Peredaran Tumbuhan dan Satwa Liar. Selain itu, juga diperlukan ijin Balai Konservasi Sumber Daya Alam yang mana Surat ijin memelihara hewan langka harus memenuhi syarat diantaranya proposal izin menangkarkan atau memelihara hewan yang diajukan ke BKSDA, salinan Kartu Tanda Penduduk untuk individu atau perseorangan serta akta notaris untuk badan usaha, surat Bebas Gangguan Usaha dari kecamatan setempat. Surat ini berisi keterangan bahwa aktifitas penangkaran dan pemeliharaan hewan tidak menganggu 
Ferna Lukmia: Tindak Pidana Perdagangan...

lingkungan sekitar, bukti tertulis asal usul indukan. ${ }^{11}$ Dalam hal pengiriman atau pengangkutan tumbuhan dan satwa dilindungi ke suatu tempat di wilayah Republik Indonesia dan atau keluar wilayah Republik Indonesia harus didasarkan pada ijin Menteri yang mana pengiriman atau pengangkutan satwa tersebut harus dilengkapi dengan dokumen resmi yakni sertifikat kesehatan satwa dari instasi yang berwenang dan dilakukan sesuai persyaratan teknis tertentu.

Pelanggaran atas Pasal 21 UU KSDAHE berimplikasi pada konsekuensi yuridis berupa sanksi pidana pada Pasal 40 ayat (2) dan ayat (4) UU KSDAHE yakni:

(2) Barang siapa dengan sengaja melakukan pelanggaran terhadap ketentuan sebagaimana dimaksud dalam Pasal 21 ayat (1) dan ayat (2) serta Pasal 33 ayat (3) dipidana dengan pidana penjara paling lama 5 (lima) tahun dan denda paling banyak Rp. 100.000.000,00 (seratus juta rupiah).

(4) Barang siapa karena kelalaiannya melakukan pelanggaran terhadap ketentuan sebagaimana dimaksud dalam Pasal 21 ayat (1) dan ayat (2) serta Pasal 33 ayat (3) dipidana dengan pidana kurungan paling lama 1 (satu) tahun dan denda paling banyak Rp. 50.000.000,00 (lima puluh juta rupiah).

Disamping itu, UU PTPPU sebagai regulasi di dalam tindak pidana pencucian uang dimaksudkan untuk mencegah dan memberantas tindak pidana pencucian uang, hal ini direalisasikan dengan cara kriminalisasi atas semua perbuatan dalam setiap tahap proses pencucian uang. Namun sedikit kasus yang diputus menggunakan undang-undang pencucian uang, padahal hal ini dapat dipraktekkan dalam kasus-kasus pidana.

Aspek lain yang perlu diperhatikan dalam hal ini adalah predicate crime atau tindak pidana asal yang diatur dalam Pasal 2 UU PTPPU. Tindak pidana pencucian uang merupakan proses penyembunyian atau penyamaran harta kekayaan yang dihasilkan dari tindak pidana asal. Tindak pidana asal merupakan tindak pidana yang menjadi sumber asal dari dirty money atau hasil tindak pidana (criminal proceeds).

${ }^{11}$ Bernadetha Aulia Oktavira, 'Jika Hewan yang Dilindungi Terlanjur Dipelihara, Hukum Online (2019), <https://www.hukumonline.com/klinik/detail/ulasan/lt5e021933a6864/jikahewan-yang-dilindungi-telanjur-dipelihara>, Diakses 15 Feburari 2020. 
Dalam undang-undang tersebut dikenal adanya Prinsip Know Your Customer (KYC) yangmana wajib dilaksanakan bank untuk mengenali nasabahnya seperti identitas nasabah, prosedur penerimaan nasabah, pemantauan nasabah secara kontinu, dan pelaporan kepada pihak yang berwenang. Prinsip tersebut merupakan rekomendasi dari FATF dalam Core Principle for Effective Banking Supervision and Basel Committee. Selain itu, peran PPATK (Pusat Pelaporan dan Analisis Transaksi Keuangan) juga mempengaruhi penegakan tindak pidana ini seperti pemeriksaan dan penghentian sementara transaksi, merekomendasi penyadapan, melakukan peraturan informasi, melakukan kerjasama dalam dan luar negeri baik bilateral maupun multilateral. ${ }^{12}$

Perdagangan di bidang bisnis dan ide lain yang berkaitan dengan bisnis keuangan serta gagasan terkait kelangsungan suatu bisnis sebagian besar menjadi sarana untuk melakukan kejahatan terorganisasi. Hal ini biasanya berkaitan dengan aktifitas illegal yang bertujuan untuk menghasilkan keuntungan. ${ }^{13}$ Tidak salah jika kejahatan terorganisasi dikaitkan dengan perdagangan yang menghasilkan keuntungan. Perdagangan satwa liar dilindungi adalah salah satu kejahatan terorganisir yang memiliki jaringan luas dan kuat serta modus perdagangan satwa liar dilindungi terus berkembang, bahkan beberapa kasus perdagangan satwa liar dilindungi tersebut dilakukan oleh eksportir satwa liar yang telah memiliki ijin resmi. Perdagangan satwa liar dilindungi yang dilakukan secara konvensional dilakukan dengan cara bertemu dan bertransaksi secara langsung antara penjual dan pembeli. Modus yang digunaan pelaku dalam perdagangan satwa dilindungi kini semakin berkembang seiring dengan pesatnya kemajuan teknologi.

Salah satu modus operasi yang dijerat menggunakan undang-undang tersebut yakni perdagangan satwa dilindungi oleh kelompok pedagang melalui grup komunikasi pedagang dalam sosial media Facebook atau yang lain, lalu

\footnotetext{
${ }^{12}$ Toetik Rahayuningsih, 'Analisis Peran PPATK Sebagai Salah Satu Lembaga Dalam Menanggulangi Money Laundering di Indonesia', (2013) 23 (28) Jurnal Yuridika : Fakultas Hukum Universitas Airlanngga.[328].

${ }^{13}$ M. Michelle Gallant, Money Laundering and Proceeds of Crime (Economic Crime and Civil Remedies (Edward Elgar Publishing 2005).[3].
} 
Ferna Lukmia: Tindak Pidana Perdagangan...

mereka melengkapi grup penjualan dengan sarana transaksi bersama atau rekber (rekening bersama). Rekber memiliki fungsi sebagai pihak ketiga antara pedagang dan pembeli. Jika jual beli antara kedua pihak sepakat, maka pembeli mengirim uang ke rekber dan penjual mengirim satwa yang dimaksud.

Konsumen perdagangan satwa liar dilindungi tidak terjadi hanya berada di ruang lingkup regional Indonesia namun juga digemari oleh konsumen dari luar negeri. Beberapa diantaranya diperdagangkan dalam bentuk barang kerajinan atau souvenir dari bagian tubuh satwa yang dilindungi di Indonesia. Modus lain terkait perdagangan satwa liar dilindungi yakni perdagangan satwa liar dilidungi tanpa disertai dokumen pengiriman. Pengangkutan satwa tersebut dikirim dengan cara menyelundupkannya menuju Indonesia atau dari Indonesia menuju negara lain. Modus lain dapat berupa pengimporan satwa secara illegal. Dalam hal ini modus yang digunakan yakni melakukan penyelundupan satwa dari luar negeri yang seharusnya dilengkapi Health Certificate dari negara asal dan melakukan karantina namun pelaku tidak melewati semua prosedur tersebut. Modus selanjutnya yang digunakan pelaku untuk melakukan kejahatan ini yakni menggunakan kemasan yang samar untuk terdeteksi secara kasat mata.

Perdagangan satwa liar dilindungi memang terjadi secara kompleks dan berbeda-beda. Karakteristik dari tindak pidana ini yakni bagian atau produk satwa keduanya dikirim atau diangkut lewat udara dari yurisdiksi asal ke yurisdiksi tujuan dan biasanya menggunakan rute tidak langsung untuk mengindari deteksi sering disembunyikan pada muatan yang sah. Pedagang satwa liar ini punya speliasiasi tersendiri dan mereka sudah tahu pembelinya seperti apa dengan baik. Bagian tubuh satwa yang dijual illegal, tetapi mereka punya jalan sendiri sehingga bisa masuk pada legal market. ${ }^{14} \mathrm{Hal}$ ini yang menyebabkan kejahatan ini sulit untuk terdeteksi dan sangat mungkin untuk terjadi pencucian uang guna menyamarkan hasil usaha jual beli satwa liar dilindungi.

${ }^{14}$ UNODC, 'Research Report Enhacing the Detection, Investigation and Disruption of Illicit Financial Flows from Wildlife Crime', United Nations Office on Drugs and Crime (2017), <https:// www.unodc.org/documents/southeastasiaandpacific/Publications/2017/FINAL_-_UNODC_ APG_Wildlife_Crime_report.pdf>, Diakses 5 Oktober 2019. 
Perdagangan satwa liar dilindungi sebagai tindak pidana asal melibatkan berbagai oknum seperti pemerintahan, ahli sektor privat, komunitas sipil untuk mendapatkan keuntungan sehingga kejahatan ini menjadi kejahatan terstruktur dan sulit untuk terdeteksi. Tidak hanya dalam jual beli dalam negeri saja, satwasatwa tersebut dengan berbagai modus dapat dikirim ke luar negeri untuk digunakan pembeli dengan berbagai dasar, mulai dari koleksi, obat-obatan, bahkan industri, hal ini akan menjadi masalah jika satwa tersebut merupakan satwa liar dilindungi. Aspek pidana dalam kejahatan ini juga semakin luas jika pelaku tidak hanya terbatas pada perorangan namun juga korporasi. Pasar illegal ini semakin berkembang ketika permintaan pasar terkait satwa dilindungi tersebut tinggi.

\section{Pertanggungjawaban Pidana}

Asas dalam pertanggungjawaban dalam hukum pidana ialah tidak dipidana jika tidak ada kesalahan (geen strafzonder schuld, actus non facit reum nisi mens sir rea). ${ }^{15}$ Simon mengatakan bahwa kesalahan adalah adanya keadaan fisik yang tertentu pada orang yang melakukan perbuatan pidana dan adanya hubungan antara keadaan tersebut dengan perbuatan yang dilakukan sedemikian rupa, hingga orang itu dicela karena perbuatan tadi. ${ }^{16}$ Dari asas pertanggungjawaban tersebut maka dapat diartikan bahwa orang tidak mungkin dipertanggungjawabkan (dijatuhi pidana) jika dia tidak melakukan perbuatan pidana. Sehingga untuk adanya kesalahan maka:

1. Melakukan perbuatan pidana (sifat melawan hukum);

2. Di atas umur tertentu mampu bertanggungjawab;

3. Mempunyai bentuk kesalahan yang berupa kesengajaan atau kealpaan;

4. Tidak ada alasan pemaaf. ${ }^{17}$

Dalam konteks perdagangan satwa liar dilindungi maka kesalahan secara eksplisit ditulis di dalam Pasal 21 ayat (2) UU KSDAHE yang melarang perniagaan satwa yang dilindungi dalam keadaan hidup, perniagaan satwa dalam keadaan

\footnotetext{
${ }^{15}$ Moeljatno, Asas-Asas Hukum Pidana (Rineka Cipta 2008).[155].

16 ibid. [158].

17 ibid.[164].
} 
Ferna Lukmia: Tindak Pidana Perdagangan...

mati, perniagaan kulit, tubuh, atau bagian-bagian lain satwa yang dilindungi atau barang-barang yang dibuat dari bagian-bagian tersebut dari suatu tempat di Indonesia ke tempat lain di dalam atau di luar Indonesia, serta memperniagakan telur dan atau sarang satwa yang dilindungi.

Perkembangan sistem pertanggungjawaban pidana dibagi menjadi tiga teori yakni teori identifikasi, teori strict liability, dan teori vicarious liability. Dalam teori identifikasi tindakan pengurus atau pegawai sebagai personil suatu korporasi diidentifikasikan sebagai tindakan korporasi. Menurut I.S Susanto pada doktrin strict liability (tanggungjawab langsung), pertanggungjawaban pidana pada pelaku tanpa membuktikan adanya kesalahan pada pelaku. Pada teori strict lability pertanggungjawban pidana dimintakan kepada pelakunya yakni badan hukum atau korporasi dan subjek hukum manusia yang melakukan perbuatan pidana dengan kategori pelanggaran. Perbuatan pidana yang bersifat strict liability hanya dibutuhkan dugaan atau pengetahuan dari pelaku, sudah cukup menuntut pertanggungjawaban pidana dari padanya. ${ }^{18}$ Lain halnya dengan teori identifikasi, teori vicarious liability menjerat kesalahan semua karyawan. Dalam teori ini pertanggungjawaban pidana atas perbuatan atau perilaku terdakwa sebagai personifikasi dari korporasi yang diwakilinya menjadi tugas dan tanggungjawab secara kolektif.

\section{Subjek Pelaku}

UU KSDAHE telah mengatur pertanggungjawaban pidana bagi pelaku natuurlijk person perdagangan satwa liar dilindungi. Sedangkan pada UU PTPPU mengatur pertanggungjawaban pidana perseorangan dan korporasi. Kesengajaan dan kealpaan suatu korporasi, didasarkan pada masalah kejiwaan dan sikap batin dapat dilakukan dengan melihat apakah kesenjangan atas tindakan para pengurus pada kenyataannya tercakup dalam politik perusahaan atau berada didalam

${ }^{18}$ Eko Ardiansyah Pandiangan, 'Penerapan Prinsip Strict Libility dalam Pertanggungjawaban Korporasi yang Dianggap Bertanggungjawab Atas Kebakaran Hutan Di Provinsi Riau’, (2016) 2 (3) Jurnal Ilmu Hukum Riau.[2]. 
kegiatan yang nyata dari suatu perusahaan tertentu. Apa yang dilakukan oleh pengurus harus dapat dipertanggungjawabkan kepada badan hukum. ${ }^{19}$

P.A.F. Lamintang menjelaskan pelaku (dader) dalam tindak pidana. Pada delik formal, pelaku dapat ditemukan dengan melihat siapa yang melakukan pelanggaran terhadap peraturan perundang-undangan pidana. Sedangkan pada delik materiil, pelaku dibagi menjadi lima kategori yakni mereka yang melakukan (plegen), mereka yang menyuruh (doen plegen), yang turut melakukan (medeplegen), yang menggerakkan orang lain (uitlokken), serta yang memberikan bantuan (medeplichtige) ${ }^{20}$

Dalam perkara perdagangan satwa liar dilindungi melibatkan banyak pihak di dalamnya mulai dari pemburu, bandar, penampung, taxidermist (pembuat satwa awetan) hingga eskportir illegal. Masing-masing aktor di dalam kejahatan ini memiliki peran yang berbeda-beda. Adapun kerjasama antar pihak dikenakan Pasal 55 KUHP terkait turut serta.

Konsep pelaku kejahatan yang semula hanya orang peorangan saja, maka sekarang dikenal pula korporasi. Beberapa regulasi dalam hukum pidana juga telah mengatur korporasi sebagai subjek tindak pidana seperti Undang-Undang Nomor 7 Drt Tahun 1955 tentang Pengusutan, Penuntutan, dan Peradilan Tindak Pidana Ekonomi,Undang-Undang Nomor 20 Tahun 2001 tentang Pemberantasan Tindak Pidana Korupsi, serta UU PTPPU. Pasal 1 angka 9 UU PTPPU yakni setiap orang adalah orang perseorangan maupun korporasi. Pasal 1 angka 10 UU PTPPU juga telah memberikan pengertian korporasi yakni kumpulan orang dan/atau kekayaan yang terorganisasi, baik merupakan badan hukum maupun bukan badan hukum.

Peraturan Mahkamah Agung Nomor 13 Tahun 2006 tentang Tata Cara Penanganan Perkara Tindak Pidana oleh Korporasi menyebutkan bahwa korporasi sebagai entitas atau subjek hukum yang keberadaannya memberikan kontribusi

\footnotetext{
${ }^{19}$ Eva Syahfitri Nasution, 'Pertanggungjawaban Pidana Korporasi dalam Tindak Pidana Pencucian Uang', (2015) 2 (8) Jurnal Mercatoria.[142].

${ }^{20}$ P.A.F. Lamintang, Dasar-Dasar Hukum Pidana Indonesia (Citra Aditya Bakti 1996).[590].
} 
meningkatkan pertumbuhan ekonomi dan pembangunan nasional. Korporasi ada kalanya melakukan berbagai tindak pidana (corporate crime) yang memberikan dampak kerugian terhadap Negara dan masyarakat. Korporasi dapat menjadi tempat menyembunyikan harta hasil kekayaan hasil tindak pidana yang tidak tersentuh proses hukum dalam pertanggungjawaban pidana (criminal liability).

Dalam hal suatu korporasi bekerjasama dengan pemburu satwa dilidungi maka korporasi tersebut dimintakan tanggungjawab pidana karena telah turut serta dalam tindak pidana perdagangan satwa liar dilindungi. Hal ini akan berkaitan dengan UU PTPPU jika korporasi telah menyembunyikan asal-usul dana dari tindak pidana perdagangan satwa liar dilindungi tersebut.

\section{Sanksi Pidana Bagi Pelaku Tindak Pidana Pencucian Uang Yang Tindak Pidana Asalnya Perdagangan Satwa Yang Dilindungi}

Tindak pidana pencucian uang sebagai kejahatan yang bersifat follow up crime atau kejahatan lanjutan, sedangkan kejahatan utama atau asalnya atau biasa disebut predicate offense atau core crime yaitu kejahatan asal yang menghasilkan uang yang kemudian dilakukan proses pencucian. Apabila dicermati bunyi dari Pasal 2 ayat (1) huruf z UU PTPPU yaitu "tindak pidana lain yang diancam dengan pidana penjara 4 (empat) tahun atau lebih", berarti dapat diketahui terdapat beberapa unsur yaitu :

1. Unsur pertama yaitu "tindak pidana lain yang diancam dengan pidana penjara" selain tindak pidana yang telah disebutkan dalam Pasal 2 ayat (1) huruf a sampai huruf y.

Artinya semua tindak pidana lain yang menghasilkan harta kekayaan selain dari yang disebutkan dalam rumusan Pasal 2 ayat (1) huruf a sampai huruf y, merupakan hasil tindak pidana.

2. Unsur kedua yaitu, agar penafsiran terhadap Pasal 2 ayat (1) huruf z tidak terlalu luas, maka dalam rumusan Pasal 2 ayat (1) huruf z memberikan standar minimal khusus terhadap sanksi pidana penjara yaitu "pidana penjara 4 (empat) tahun atau lebih". 
Artinya semua tindak pidana yang diancam dengan pidana penjara 4 (empat) tahun atau lebih, selain dari yang disebutkan dalam rumusan Pasal 2 ayat (1) huruf a sampai huruf y, merupakan hasil tindak pidana.

Sehingga UU PTPPU mengatur tentang, tetapi juga termasuk tindak pidana lain dengan ancaman pidana penjara 4 tahun atau lebih.

Pada dasarnya kejahatan konservasi sebagaimana diatur dalam UU KSDAHE masuk dalam kategori dalam Pasal 2 UU PTPPU. Mengingat bahwa UU PTPPU mengakomodir proceeds of crime terkait kejahatan di bidang kehutanan, lingkungan hidup, serta bidang kelautan dan perikanan. Selain itu, pelaku melakukan pelanggaran terhadap Pasal 40 UU KSDAHE yang mendapat ancaman penjara lebih dari empat tahun sehingga masuk di dalam unsur tindak pidana lain dengan ancaman pidana penjara 4 tahun atau lebih.. Maka pelaku sesungguhnya dapat dikenakan ketentuan tindak pidana pencucian uang sebagaimana dalam UU PTPPU.

Pola aliran dana hasil tindak pidana perdagangan satwa liar dilindungi bernilai tinggi dan riskan melewati batas negara. Instrumen tindak pidana pencucian uang merupakan langkah strategis guna menjerat pelaku perdagangan satwa liar dilindungi. Meskipun UU KSDAHE belum mengatur subjek pelaku korporasi dalam hal perdagangan satwa liar dilindungi, namun UU PTTPU telah mengakomodir subjek pelaku baik perseorangan maupun korporasi yang menyembunyikan asal usul hasil tindak pidana perdagangan satwa liar dilindungi ke dalam sistem ekonomi sehingga sulit untuk terdeteksi. Terlebih lagi di dalam ketentuan UU PTPPU mengatur ancaman pidana pokok baik penjara dan denda yang lebih tinggi daripada UU KSDAHE. Selain itu, terdapat kemungkinan untuk dilakukannya perampasan aset dan perampasan keuntungan serta pemberlakuan pembalikan pembuktian. Penerapan UU PTPPU sangat diutamakan untuk diterapkan pada pelaku pelaku kejahatan konservasi sehingga dapat menimbulkan efek jera dan deterensi nyata pada pelaku kejahatan.

Korporasi di dalam kejahatan perdagangan satwa liar dilindungi memiliki peran cukup besar di dalamnya. Perusahaan-perusahaan kuat juga terlibat di 
Ferna Lukmia: Tindak Pidana Perdagangan...

dalam kejahatan lingkungan. ${ }^{21}$ Salah satunya, kejahatan satwa liar tersebut terjadi atas permintaan korporasi dalam memproduksi luxury product. Seperti dalam kasus Zhifei Li, seorang pemilik bisnis antik di China dijatuhi hukuman 70 bulan karena menyelundupkan 30 cula badak. Li membeli dua buah tanduk hitam yang terancam punah dari agen US Fish dan Wildlife Service yang menyamar di Miami, Florida seharga 59.000 US dollar sebelum penangkapnnya. Lalu ia menjual ke pabrik-pabrik Cina yang membuat cangkir minum berukir dari tanduk. Cangkir tersebut diyakini membawa dampak kesehatan yang baik. ${ }^{22}$ Dalam kasus ini, Li memainkan peran sebagai pemimpin dalam organisasi yang melakukan konspirasi penyelundupan dengan mengatur pembiayaan untuk membayar satwa liar, membeli dan menegosiasikan harga, mengarahkan bagaimana penyelundupan tersebut dapat keluar dari Amerika Serikat, dan mendapatkan bantuan dari kolaborator tambahan dari Hongkong untuk menerima barang selundupan tersebut dan menyelundupkannya di daratan China. ${ }^{23}$

Permintaan yang tinggi terhadap bagian satwa liar dilindungi ini untuk kegiatan produksi di bidang tekstil, fashion (trading company), dan obat-obatan terlebih lagi jika produsen merupakan korporasi yang besar sehingga hasil kejahatan perdagangan satwa dilindungi tersebut tersamarkan. Motif ekonomi sebagian korporasi untuk memperoleh keuntungan dan kekayaan yang besar menimbulkan kerugian kepada masyarakat, warga negara, dan dilakukan dengan modus operandi tertentu. ${ }^{24}$ Dalam hal ini, UU PTPPU memuat aturan yang mendukung upaya untuk memberantas perdagangan satwa liar dilindungi.

Hal ini dapat menjadi langkah yang progresif dalam menjerat pelaku tindak pidana perdagangan satwa liar dilindungi. UU KSDAHE masih belum menjangkau

${ }^{21}$ Daan P. van Uhm, 'Wildlife and Laundering: Interaction Between The Under and Upper World Research Gate', (2018), Utrecht University.[98].

${ }^{22}$ WWF, 'US Imposes One of the Longest Sentences to Wildlife Trader', World Wide Fund for Nature, (2014), <https:/ / www.worldwildlife.org>, Diakses 10 Desember 2019.

${ }^{23}$ The United States Department of Justice, 'Ringleader of International Rhino Smuggling Conspiracy Sentenced in New Jersey to 70 Months in Prisonfor Wildlife Trafficking Crimes, The United States Attorneys's Office District of New Jersey, (2014), <https://www.justice.gov/opa/pr> 28 Mei 2014, Diakses 10 Desember 2019.

${ }^{24}$ Setiyono, 'Kejahatan Korporasi Analisis Viktimologi dan Pertanggungjawaban Korporasi dalam Hukum Pidana Indonesia', (Bayumedia Publishing 2005).[44]. 
subyek atau pelaku korporasi. Selain, itu beberapa kasus telah perdagangan satwa liar dilindungi tersebut tidak hanya terjadi antara subjek individu tetapi juga atas permintaan korporasi, baik dalam rangka memenuhi kebutuhan produksinya atau mendapatan keuntungan yang lebih besar. Beberapa kasus melibatkan korporasi, baik korporasi dengan bentuk badan hukum maupun non badan hukum, beberapa diantaranya terjadi pada lembaga konservasi dan lembaga penangkaran seperti PT Nuansa Alam Nusantara Lembaga, di Padang Lawas dan CV Bintang Terang di Jawa Timur. ${ }^{25}$

Hal ini tidak menutup kemungkinan adanya korporasi lain yang masih belum terdeteksi karena bentuk modus pelaku yang menyamarkan asal usul atau menyembunyikan keuntungan hasil perdagangan satwa liar dilindungi sehingga menyulitkan aparat hukum untuk mendeteksi kejahatan tersebut. Sehingga korporasi yang seharusnya melanggar beberapa aturan dalam UU KSDAHE dapat dikenakan regulasi pada UU PTTPU.

Dalam konteks korporasi yang menjadi subjek dalam perdagangan satwa liar dilindungi maka korporasi atau perusahaan dapat menyembunyikan hasil kejahatan dalam aktivitas normal dari usaha yang dimilikinya. Dalam hal ini korporasi melalui perusahaan legal nya membeli satwa liar dilindungi dari wildlife trader or breeder. Pembayaran diberikan kepada pemburu untuk mendapatkan hasil buruan berupa satwa liar dilidungi. Hasil buruan akan diberikan kembali pada wildlife trader or breeder untuk diberikan pada pembeli, dalam hal ini adalah korporasi.

UU PTPPU telah mengatur tindak pidana pencucian uang pada subjek hukum orang dan korporasi. Pelaku tindak pidana pencucian uang dapat menjadi pelaku aktif atau pelaku utama dalam hal ini dapat dijerat Pasal 3 atau Pasal 4 UU PTTPU dan juga pelaku pasif yangmana dapat dijerat pada Pasal 5 UU PTPPU. Pasal 3 UU PTPPU mengatur pelaku dalam pencucian uang dengan tujuan untuk

${ }^{25}$ ICEL, 'Proyeksi Penerapan Pertanggungjawaban Korporasi dalam Kejahatan Konservasi', Indonesia Center for Environmental Law (2019), <https://icel.or.id/kertas-kebijakan/proyeksipenerapan-pertanggungjawaban-korporasi-dalam-kejahatan-konservasi/ > , Diakses 2 Mei 2020. 
Ferna Lukmia: Tindak Pidana Perdagangan...

menyembunyikan atau menyamarkan asal usul harta kekayaan dari tindak pidana asal. Dalam hal ini, pelaku perdagangan satwa liar dilindungi melakukan jual beli sehingga mendapatkan keuntungan, profit yang didapat tersebut disamarkan dengan cara memasukkan keuntungan perdagangan satwa liar dilindungi ke dalam korporasi yang dimilikinya. Hal ini dilakukan seolah-olah profit hasil perdagangan tersebut merupakan uang yang sah di dalam korporasi, contohnya dimasukkan pada lembaga penangkaran yang dimilikinya.

Pasal 3

Setiap Orang yang menempatkan, mentransfer, mengalihkan, membelanjakan, membayarkan, menghibahkan, menitipkan, membawa ke luar negeri, mengubah bentuk, menukarkan dengan mata uang atau surat berharga atau perbuatan lain atas Harta Kekayaan yang diketahuinya atau patut diduganya merupakan hasil tindak pidana sebagaimana dimaksud dalam Pasal 2 ayat (1) dengan tujuan menyembunyikan atau menyamarkan asal usul Harta Kekayaan dipidana karena tindak pidana Pencucian Uang dengan pidana penjara paling lama 20 (dua puluh) tahun dan denda paling banyak Rp10.000.000.000,00 (sepuluh miliar rupiah).

Pelaku pencucian uang secara aktif melakukan perbuatan sebagaimana dirumuskan pada Pasal 3 UU PTTPU, dimana pelaku pencucian uang merupakan pelaku tindak pidana asal dari harta kekayaan sehingga pelaku mengetahui harta kekayaan tersebut merupakan hasil tindak pidana. Korporasi dapat melakukan perdagangans satwa liar dilindungi. Lembaga penangkaran yang dikelolanya dapat menjadi modus untuk melakukan pencucian uang. Seolah-olah korporasi tersebut melakukan kegiatan yang sah, namun perdagangan satwa liar dilindungi justru dilakukan oleh lembaga konservasi yang seharusnya berfungsi menjaga kelestarian satwa liar dilidungi.

Pasal 4

Setiap Orang yang menyembunyikan atau menyamarkan asal usul, sumber, lokasi, peruntukan, pengalihan hak-hak, atau kepemilikan yang sebenarnya atas Harta Kekayaan yang diketahuinya atau patut diduganya merupakan hasil tindak pidana sebagaimana dimaksud dalam Pasal 2 ayat (1) dipidana karena tindak pidana Pencucian Uang dengan pidana penjara paling lama 20 (dua puluh) tahun dan denda paling banyak Rp5.000.000.000,00 (lima miliar rupiah).

Pelaku pencucian uang sebagaimana dirumuskan pada Pasal 4 UU PTPPU merupakan pelaku aktif seperti Pasal 3 UU PTPPU, namun perbuatan aktif yang dilakukan pelaku pencucian uang berbeda. Pasal 4 UU PTPPU merupakan regulasi yang menjerat pelaku yang menyembunyikan asal usul dan sumber hasil tindak pidana pencucian uang sebagaimana dalam rumusan yang ada pada Pasal 4 UU PTPPU. 
Pasal 5

(1) Setiap Orang yang menerima atau menguasai penempatan, pentransferan, pembayaran, hibah, sumbangan, penitipan, penukaran, atau menggunakan Harta Kekayaan yang diketahuinya atau patut diduganya merupakan hasil tindak pidana sebagaimana dimaksud dalam Pasal 2 ayat (1) dipidana dengan pidana penjara paling lama 5 (lima) tahun dan denda paling banyak Rp1.000.000.000,00 (satu miliar rupiah).

(2) Ketentuan sebagaimana dimaksud pada ayat (1) tidak berlaku bagi Pihak Pelapor yang melaksanakan kewajiban pelaporan sebagaimana diatur dalam Undang-Undang ini.

Perumusan pencucian uang berupa bentuk menikmati manfaat dari hasil kejahatan atau berpartisipasi menyembunyikan atau menyamarkan asal usul harta kekayaan. Pelaku pencucian uang belum tentu melakukan tindak pidana asal dan mengetahui pasti asal usul harta kekayaan.

Dalam hal ini korporasi menerima hasil penempatan perdagangan satwa liar dilindungi untuk masuk menjadi bahan baku perusahannya. Pasal 5 UU PTTPU mengakomodir Concealment Within Business Structures. Upaya korporasi dilakukan dengan cara menerima hasil tindak pidana melalui financial system lalu mencampurnya dengan bisnis yang dimiliki korporasi tersebut membuat transaksi yang terjadi pada korporasi minim kecurigaan. Terlebih lagi korporasi biasa untuk melakukan transaksi antar yurisdiksi dan mata uang. Korporasi tersebut akan mudah bertransaksi dalam membeli perdagangan satwa liar dilindungi terlebih lagi bila korporasi merupakan perusahaan internasional yang memiliki official store pada masing-masing negara. Hal penting lain yang juga dimiliki oleh UU PTPPU adalah perampasan aset korporasi sebagaimana diatur dalam Pasal 7 UU PTPPU.

Korporasi dapat menerima hasil kejahatan perdagangan satwa liar dilindungi, dalam hal ini tidak perlu melakukan perdagangan satwa liar dilindungi. Pada kasus perdagangan satwa liar dilindungi yang dilakukan oleh Teng Group, jual beli satwa antar negara dilakukan melalui shipping container. Kelompok kejahatan tersebut memiliki perusahaan impor dan ekspor di Yaonde. ${ }^{26} \mathrm{Hal}$ ini tidak menutup kemungkinan jika perusahaan yang dimiliki pelaku perdagangan

${ }^{26}$ UNODC, ‘University Module Series Illicit Markets for Wildlife, Forest and Fisheries Products', United Nations Office on Drugs and Crime (2019), <https://www.unodc.org/e4j/en/ wildlife-crime/module-1/index.html>, Diakses3 Mei 2020. 
satwa liar dilindungi dapat menerima keuntungan hasil perdagangans satwa liar didlindungi dan memasukkan hasil keuntungannya pada perusahaan tersebut. Keuntungan tersebut sulit terdeteksi karena telah masuk pada sistem ekonomi di dalam perusaah sah yang dimiliki.

Korporasi dapat menjadi sarana untuk menyembunyikan harta kekayaan hasil tindak pidana atau Exploiting International Jurisdiction Issue, dalam hal ini perusahaan sengaja didirikan untuk menyembunyikan dan menyamarkan harta kekayaan yang berasal dari tindak pidana di luar negeri. Korporasi yang menerima hasil tindak pidana yang dicampur dengan usahanya yang sah disebut Concealment Within Business Structures. Selain itu juga terdapat penyalahgunaan perusahaan sah untuk menyembunyikan dan menyamarkan hasil tindak pidana atau disebut Misuse Legitimate Business. ${ }^{27}$

Perdagangan satwa liar dilindungi sebagai kejahatan terorganisasi sangat erat kaitannya dengan aset. Kejahatan ini akan lebih efektif jika dilakukan perampasan atas keuntungan perdagangan satwa liar yang sangat tinggi. Perampasan aset dapat menjadi langkah untuk proses rehabilitasi atas terganggunya sistem konservasi akibat perdagangan satwa liar dilindungi.

Rezim antipencucian menjalankan fungsi penting dalam kejahatan ini. Maka dari itu, kriminalisasi suatu tindak pidana melalui regulasi dalam tindak pidana pencucian uang diperlukan untuk mencegah kejahatan asal semakin berkembang, memberikan sanksi dalam hal lalu lintas keuangan hasil suatu tindak pidana. Pelaku tidak hanya dikenakan sanksi terkait perdagangan satwa liar dilindungi saja, namun juga terkait hasil keuangan dari perdagangan satwa liar dilindungi tersebut.

\section{Kesimpulan}

UU KSDAHE merupakan regulasi yang mengatur perbuatan yang dilarang terkait perdagangan satwa liar dilindungi. Sebagai tindak pidana asal pada Pasal 2 UU PTPPU, perdagangan satwa liar dilindungi sebagai kejahatan organisasi

${ }_{27}$ Yusuf Husein, 'TPK, TPPU, dan Pertanggungjawaban Pidana Korporasi', (2019), <https:// www.persi.or.id/images/2019/data/materi_dari_kpk/ccl_profit.pdf>, Diakses 25 Desember 2019. 
memiliki beberapa modus operandi meliputi perdagangan online, offline, atau penyelundupan dengan lalu lintas dana tidak hanya pada sektor nasional namun antar negara. Pelaku tersebut memiliki jalan sendiri sehingga bisa masuk pada legal market sehingga sulit terdeteksi dan dapat menjadi jalan menyamarkan hasil usaha jual beli satwa liar dilindungi. Permintaan yang besar untuk koleksi, obat-obatan, bahkan industri, menjadi masalah karena pasar illegal ini semakin berkembang ketika permintaan tersebut tinggi.

Terdapat dua macam subjek pelaku dalam perdagangan satwa dilindungi yang berimplikasi pada tindak pidana pencucian uang yakni natuurlijk person dan recht person. UU KSDAHE belum mengatur subjek hukum korporasi. Terkait aliran dana hasil perdagangan satwa dilindungi, pelaku natuurlijk person dan recht person dapat dijerat menggunakan rezim UU PTPPU karena korporasi dapat menjadi sarana untuk menyembunyikan dan menyamarkan hasil tindak pidana perdagangan satwa liar dilindungi sehingga sulit terdeteksi oleh aparat hukum.

\section{Daftar Bacaan}

\section{Buku}

M. Michelle Gallant, Money Laundering and Proceeds of Crime (Economic Crime and Civil Remedies (Edward Elgar Publishing 2005)

Moeljatno, Asas-Asas Hukum Pidana (Rineka Cipta 2008).

P.A.F. Lamintang, Dasar-Dasar Hukum Pidana Indonesia (Citra Aditya Bakti 1996).

Salim, Dasar-Dasar Hukum Kehutanan (Sinar Grafika 2008).

Setiyono, 'Kejahatan Korporasi Analisis Viktimologi dan Pertanggungjawaban Korporasi dalam Hukum Pidana Indonesia', (Bayumedia Publishing 2005).

\section{Jurnal dan Artikel}

Daan P. van Uhm, 'Wildlide and Laundering : Interaction Between The Under and Upper World Research Gate', (2018), Utrecht University.

Eko Ardiansyah Pandiangan, 'Penerapan Prinsip Strict Libility dalam Pertanggungjawaban Korporasi yang Dianggap Bertanggungjawab Atas 
Ferna Lukmia: Tindak Pidana Perdagangan...

Kebakaran Hutan Di Provinsi Riau', (2016) 3 (2) Jurnal Ilmu Hukum Riau.

Eva Syahfitri Nasution, 'Pertanggungjawaban Pidana Korporasi dalam Tindak Pidana Pencucian Uang', (2015) 8 (2) Jurnal Mercatoria.

S. Endang Prasetyawati, 'Analisis Penerapan Sanksi Pidana Tentang Kejahatan Konservasi Sumberdaya Alam Hayati’ (2015) 44 (22) eJournal Undip.

Toetik Rahayuningsih, 'Analisis Peran PPATK Sebagai Salah Satu Lembaga Dalam Menanggulangi Money Laundering di Indonesia', (2013) 28 (23) Jurnal Yuridika : Hukum Universitas Airlangga.

Yoshua Aristides, Agus Purnomo, Fx. Adji Samekto, ‘Perlindungan Satwa Langka di Indonesia dari Perspektif Convention on Intrenational Trade in Endangered Species of Flora and Fauna (CITES)' (2016) 5 (4) Diponegoro Law Journal.

\section{Laman}

Ahmad Nurhasim, "Indonesia Rugi 9 Triliun Akibat Perdagangan Satwa Liar", Tempo.com (online), 5 Juni 2016, https:/ / nasional.tempo.co/read/776900/ indonesia-rugi-rp-9-triliun-akibat-perdagangan-satwa-liar.

Ahmad Nurhasim, 'Indonesia Rugi 9 Triliun Akibat Perdagangan Satwa Liar', Tempo News (online) ( 2016), <https://nasional.tempo.co/read/776900/ indonesia-rugi-rp-9-triliun-akibat-perdagangan-satwa-liar>, Diakses 23 Agustus 2019.

Bernadetha Aulia Oktavira, 'Jika Hewan yang Dilindungi Terlanjur Dipelihara, Hukum Online (2019), <https://www.hukumonline.com/klinik/detail/ ulasan/1t5e021933a6864/jika-hewan-yang-dilindungi-telanjur-dipelihara>, Diakses 15 Feburari 2020.

ICEL, 'Proyeksi Penerapan Pertanggungjawaban Korporasi dalam Kejahatan Konservasi', Indonesia Center for Environmental Law (2019), <https:// icel.or.id/kertas-kebijakan/ proyeksi-penerapan-pertanggungjawabankorporasi-dalam-kejahatan-konservasi/ >, Diakses 2 Mei 2020.

ICEL, 'Proyeksi Penerapan Pertanggungjawaban Korporasi dalam Kejahatan Konservasi', Indonesia Center for Environmental Law (2019), <https:// icel.or.id/kertas-kebijakan/proyeksi-penerapan-pertanggungjawabankorporasi-dalam-kejahatan-konservasi/ >, Diakses 2 Mei 2020.

Petrus Riski, 'Pentingnya Penguatan Hukum dalam Perlindungan Satwa Liar di Indonesia', VOA Indonesia (2019), <https://www.voaindonesia.com/a/ pentingnya-penguatan-hukum-dalam-perlindungan-satwa-liar-di- 
indonesia/4825454.html>, Diakses pada tanggal 20 Agustus 2019.

Risanti, 'Pelaku Perdagangan Satwa Liar Dilindungi Akan Dijerat UU Pencucian Uang', IAR Indonesia, (2017), <http:/ / www.internationalanimalrescue.or.id/ pelaku-perdagangan-satwa-liar-dilindungi-akan-dijerat-uu-pencucianuang/, 10 Maret 2017>, Diakses pada tanggal 25 Februari 2020.

The United States Department of Justice, 'Ringleader of International Rhino Smuggling Conspiracy Sentenced in New Jersey to 70 Months in Prisonfor Wildlife Trafficking Crimes, The United States Attorneys's Office District of New Jersey, (2014), <https://www.justice.gov/opa/pr> 28 Mei 2014, Diakses 10 Desember 2019.

UNODC, 'Research Report Enhacing the Detection, Investigation and Disruption illlicit Financial Flows from Wildlife Crime', United Nations Office on Drugs and Crime (2017), <https://www.unodc.org/documents/ southeastasiaand pacific/Publications/2017/FINAL_-_UNODC_APG_ Wildlife_Crime_report.pdf $>$, Diakses 5 Oktober 2019.

WWF, 'US Imposes One of the Longest Sentences to Wildlife Trader', World Wide Fund for Nature, (2014), <https:/ / www.worldwildlife.org>, Diakses 10 Desember 2019.

The United States Department of Justice, 'Ringleader of International Rhino Smuggling Conspiracy Sentenced in New Jersey to 70 Months in Prisonfor Wildlife Trafficking Crimes, The United States Attorneys's Office District of New Jersey, (2014), <https:/ / www.justice.gov/opa/pr> 28 Mei 2014, Diakses 10 Desember 2019.

\section{Perundang-undangan}

Undang-Undang Nomor 5 Tahun 1990 tentang Konservasi Sumberdaya Alam Hayati dan Ekosistemnya (Lembaran Negara Republik Indonesia Tahun 1990 Nomor 49, Tambahan Lembaran Negara Republik Indonesia Nomor 3419).

Undang-Undang Nomor 41 Tahun 1999 tentang Kehutanan (Lembaran Negara Republik Indonesia Tahun 1999 Nomor 167; Tambahan Lembaran Negara Republik Indonesia Nomor 3888).

Undang-Undang Nomor 8 Tahun 2010 tentang Pencegahan dan Pemberantasan Tindak Pidana Pencucian Uang (Lembaran Negara Republik Indonesia Tahun 2010 Nomor 122; Tambahan Lembaran Negara Republik Indonesia Nomor 5164).

How to cite: Ferna Lukmia Sutra, 'Tindak Pidana Perdagangan Satwa Liar Dilindungi yang Berimplikasi Tindak Pidana Pencucian Uang' (2020) Vol. 3 No. 3 Media Iuris. 
-Halaman ini sengaja dibiarkan kosong-- 